\title{
KENYAMANAN DAN KEAMANAN PADA SISTEM PARKIR OTOMOTIS BERBASIS SENSOR
}

\author{
Yudi Herdiana \\ Universitas Bale Bandung \\ E-mail: ydherdn@gmail.com
}

\begin{abstract}
Abstrak: Jumlah kendaraan meningkat dari hari ke hari secara cepat, hal ini menyebabkan masalah lalu lintas kemacetan, polusi (kebisingan dan udara). Untuk mengatasi masalah ini diperlukan sebuah sistem parkir otomatis berbasis sensor. Sistem Sensor menggunakan antarmuka seperti sensor interfacing, motor stepper dan LCD. Beberapa sistem parkir ada yang melibatkan berbagai teknik sistem parkir otomatis yang dirancang menggunakan teknologi seperti Automatic Number Plate Recognition-ANPR, RFID, RPI, jaringan sensor nirkabel dan sistem pemesanan ruang otomatis berbasis WiFi tetapi menghadapi masalah-masalah tertentu dalam hal daya, biaya, efisiensi, kecepatan dan faktor eksternal lainnya. Tujuan utamanya adalah untuk mengatasi masalah di atas sehingga sistem ini dapat bekerja lebih cepat, akurat dengan tenaga manusia yang lebih sedikit, kenyamanan pengguna dan dengan biaya pemeliharaan yang lebih sedikit diperlukan. Sistem dengan biaya tenaga manusia lebih sedikit dan menjadi lebih akurat karena semuanya ditangani oleh sistem. Dalam tulisan ini, menyajikan desain dan pengembangan sistem parkir cerdas menggunakan teknologi berdasarkan pada jaringan sensor nirkabel (WSN). Sistem kami menggunakan jaringan sensor nirkabel yang beradaptasi dengan semua jenis parkir mobil yang ada di kota, dan menawarkan pengelolaan konsumsi energi yang lebih baik selama komunikasi nirkabel untuk meningkatkan seumur hidup node sensor dan umur panjang dari WSN
\end{abstract}

Kata Kunci: kenyamanan, keamanan, sensor, parkir otomatis

\section{Pendahuluan}

Parkir kendaraan menjadi masalah utama saat ini. Seiring bertambahnya jumlah penduduk, jumlah kendaraan di jalan juga meningkat yang mengarah ke area yang tidak memadai untuk memarkir kendaraan ini. Ini menciptakan masalah yang lebih besar ketika orang-orang akhirnya memarkir mobil di jalan-jalan yang menyebabkan kemacetan lalu lintas. Kemacetan lalu lintas kendaraan adalah masalah dunia. Dalam beberapa tahun terakhir, upaya telah dilakukan untuk memperkenalkan metode untuk mengurangi masalah parkir seperti kemacetan, kecelakaan dan bahaya.. Seperti yang ditunjukkan pada gambar 1, kemacetan jelas tumbuh dari tahun ke tahun. Ini menciptakan sejumlah masalah. Kemacetan biasanya berarti butuh waktu lebih lama untuk mendapatkan / dari bekerja di "jam sibuk". Sistem parkir juga dapat memanfaatkan teknologi inovatif untuk meningkatkan kemudahan dan kenyamanan membayar parkir. Sekarang sehari, kartu Smart meminimalkan waktu transaksi dengan memungkinkan pengguna untuk sekadar melambaikan kartu mereka di depan pembaca. Perangkat seluler juga dapat digunakan dalam transaksi pembayaran. Utilitas umum membutuhkan sistem parkir yang dapat berfungsi secara efisien dan terintegrasi dengan utilitas kota lainnya. 


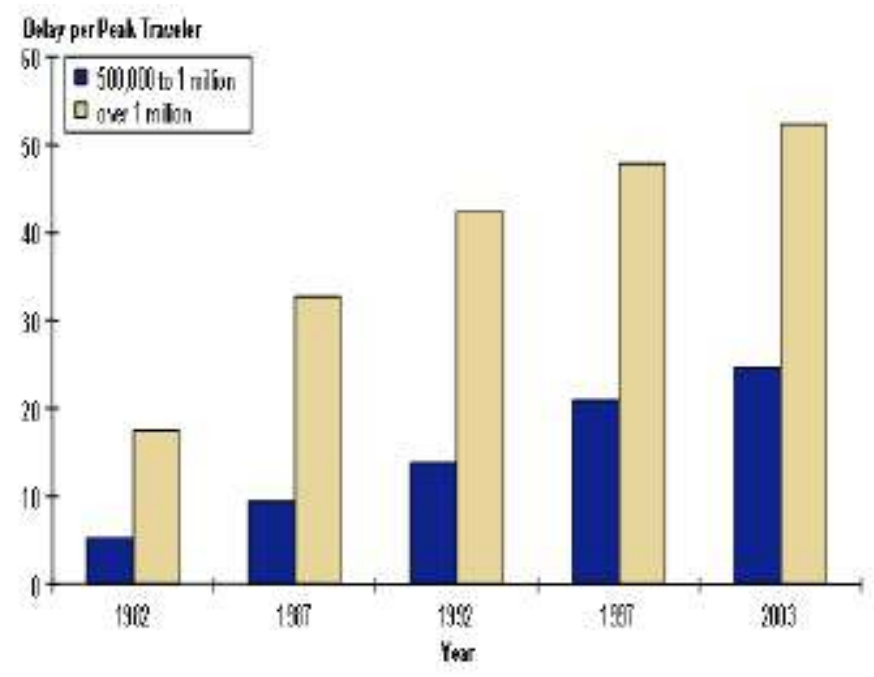

Gambar 1: Tren Kemacetan di Daerah Perkotaan

Sumber : www.ops.fhwa.dot.gov/congestion_report/chapter3.htm\#footer14

Dengan perubahan ekonomi global dan kehidupan modern, sektor Teknologi Informasi dan Komunikasi (TIK) telah mengalami percepatan vital dalam prosesnya, untuk beradaptasi pada perubahan tersebut. Saat ini, orang menghabiskan sebagian besar waktu mereka di luar lingkungan rumah mereka, mereka melakukan perjalanan setiap hari untuk bekerja, dan mereka sering pergi ke pusat perbelanjaan dan atraksi, tanpa melupakan perpindahan ke pusat kota. Hal ini tentu menyebabkan ketidakseimbangan dalam mobilitas harian yang mengarah pada pengembangan layanan parkir untuk menghindari berkendara yang tidak perlu di sekitar pusat kota hanya untuk mencari untuk tempat parkir. Ini, di satu sisi, menyebabkan emisi karbon dioksida tambahan dan merusak lingkungan ekosistem kota. Di sisi lain, itu meningkatkan kekecewaan pengemudi dan kemacetan lalu lintas di kota, yang pasti akan menyebabkan kecelakaan lalu lintas. Semua ini menurunkan pengalaman ekosistem kota modern dan telah menjadi tantangan utama dalam pengembangan masa depan sistem parkir. yang otomatis.

Sistem parkir kendaraan multilevel sangat penting terutama di daerah yang menghadapi kekurangan ruang, juga di daerah yang melayani banyak orang. Tempat parkir multi-level menawarkan yang terbaik kemungkinan fleksibilitas untuk realisasi solusi parkir yang optimal. Multi-level parkir menawarkan menyediakan proses parkir cepat di mana pengemudi tidak harus melakukan manuver mobilnya di setiap level. Sistem parkir otomatis canggih didesain dengan sangat baik diuji dan dibangun. Mereka digunakan di seluruh dunia di lokasi yang benar-benar otomatis, di mana kecepatan dan keandalan sangat penting.

Multilevel memfasilitasi parkir untuk sebagian besar tetapi untuk meningkatkan keamanan kendaraan yang diparkir serta untuk mengurangi pekerjaan manual dan waktu yang dikonsumsi selama parkir, teknik diperkenalkan dengan sistem ini bernama RFID. Waktu dan biaya merupakan dua faktor penting kehidupan manusia, baik untuk individu atau bisnis. Pengemudi harus menghabiskan banyak waktu untuk mengambil mobil dari sistem parkir kendaraan multilevel yang datang dengan posisi di tanah. Algoritme terpendek Dijkstra digunakan untuk mengambil mobil dari sistem parkir multilevel yang 
memastikan penghematan waktu. Algoritma ini bekerja berdasarkan prioritas operasi pelaksana untuk input yang diberikan.

\section{Tinjauan Pustaka}

Pencarian tanpa akhir untuk ruang bebas di tempat parkir adalah beban bagi pengemudi apa pun saat ini karena kendaraan merupakan moda transportasi yang dominan. Dengan meningkatnya jumlah kendaraan dan berkurangnya tempat parkir, kendaraan yang diparkir di sepanjang jalan dan bahkan di trotoar telah menjadi fenomena yang cukup umum. Dengan kendaraan-kendaraan yang diparkir ini merambah ruang jalan dan ruang pejalan kaki, kemacetan lalu lintas dan kecelakaan tidak dapat dielakkan. Sistem parkir yang terorganisir dengan baik yang memaksimalkan penggunaan ruang yang tersedia menawarkan solusi untuk situasi ini.

Dalam sistem parkir tradisional, kendaraan diparkir secara tegak lurus atau paralel. Tanpa pengaman terhadap perlindungan terhadap kondisi atmosfer, ini juga bukan sistem hemat ruang. Sistem parkir bertingkat lebih disukai karena mereka melipatgandakan kapasitas parkir dari suatu area tertentu [S Lee, 2008]. Berbagai lantai hadir untuk memarkir kendaraan dengan landai dan tangga yang disediakan untuk bergerak di antara lantai.

\subsection{Model Sistem Parkir yang Ada}

Sistem parkir kendaraan otomatis menggunakan RFID "Dalam RFID ini digunakan untuk mendeteksi dan mencocokkan tag RFID kendaraan yang sudah tersimpan dalam basis data. Sistem ini benar-benar memberikan keamanan kepada kendaraan seseorang ". (Hanche, S. C, 2013)

Desain dan implementasi sistem parkir pintar (SCPS) menggunakan raspberry pi "Ini mengacu pada penggunaan komputer dan teknologi informasi untuk mendeteksi tempat parkir yang tepat di area parkir tanpa membuang waktu untuk mencari tempat kosong melalui jelajah di daerah tersebut. Ini menggunakan raspberry pi, modul Wi-Fi, pemrosesan gambar dan antarmuka pengguna grafis (GUI) ". (K. Pardeshi, 2015)

Sistem parkir pintar berdasarkan sistem embedded dan jaringan sensor "Ini menggunakan sistem parkir pintar berbasis reservasi prototipe (RSPS) yang memungkinkan pengemudi untuk secara efektif mencari dan menahan ruang parkir kosong. Ini menggunakan jaringan sensor nirkabel (sensor IR), internet, sistem embedded, reservasi, alokasi sumber daya, panduan parkir dan informasi ". (F. Shaik, et.all, 2016)

Sistem deteksi ruang parkir cerdas berdasarkan pemrosesan gambar "Kamera digunakan sebagai sensor untuk pendeteksian gambar video karena kemampuan dan biaya realisasinya. Ia menggunakan deteksi tepi dengan metode batas metode untuk modul pendeteksi gambar". (R. Yusnita, 2012)

Sistem parkir kendaraan cerdas berbasis Raspberry-pi "Sistem digital dibangun dalam proyek ini yang menggunakan raspberry-pi dan komputer onboard yang akan dihubungkan dengan kamera untuk memvisualisasikan titik buta dan sensor kedekatan untuk deteksi hambatan. Prototipe sistem diimplementasikan pada mobil mainan. Tujuan 
utama dari model ini adalah untuk memecahkan masalah parkir mobil paralel dan reverse untuk pemula maupun menengah karena adanya blind spot ". (Ayesha Haroon., 2015)

\subsection{Sekilas Sistem Parkir Tradisioanal}

Pada sistem parkir tradisional, kendaraan diparkir secara tegak lurus atau paralel. Tanpa pengaman terhadap perlindungan terhadap kondisi atmosfer, ini juga bukan sistem hemat ruang. Sistem parkir bertingkat lebih disukai karena mereka melipatgandakan kapasitas parkir dari suatu area tertentu (S. Lee, 2008). Berbagai lantai hadir untuk memarkir kendaraan dengan landai dan tangga yang disediakan untuk bergerak di antara lantai. Ada berbagai jenis sistem yang ada yang diterapkan di banyak negara untuk meningkatkan fasilitas parkir untuk area padat (H. G. Jung, 2010). Ulasan ini mengidentifikasi beberapa dari mereka. Untuk mulai dengan, sistem Lot-spesifik menggunakan tanda untuk memberikan informasi parkir yang biasanya berisi petunjuk sederhana ke fasilitas parkir dan menyarankan untuk driver untuk menemukan ruang yang tersedia menggunakan tanda-tanda yang biasanya memiliki komponen pasif dan aktif (J. Takahashi, 2009).

Komponen pasif menyediakan petunjuk sederhana ke fasilitas parkir, seperti dengan panah. Komponen aktif suplemen komponen pasif untuk menyarankan wisatawan tentang ketersediaan ruang di fasilitas tersebut. Keuntungan dari sistem jenis ini adalah bahwa ia menampilkan jumlah ruang yang tersedia di pintu masuk tempat parkir mobil, di pintu masuk masing-masing tingkat dan di ujung setiap lorong. Ini juga menampilkan tanda arah untuk setiap lorong, menunjukkan arah mana yang harus diikuti pengemudi. Lampu LED warna yang berbeda membantu pengemudi untuk membedakan antara spasi (dicadangkan, ditempati, kosong atau cacat). Ini juga menghindari parkir yang tidak benar. Tipe kedua dari sistem parkir adalah Sistem Informasi Parkir Lantai-Lorong dan Ruang Angkasa. Ini memberikan informasi tentang jumlah tempat di tempat parkir, termasuk tempat yang penuh dan kosong. Mereka memberikan informasi lebih rinci dan ditempatkan di pintu masuk tempat parkir mobil, di setiap lantai, di awal setiap lorong dan bahkan di depan setiap tempat parkir. Sistem ini membantu manajemen parkir untuk mengelola persediaan parkir, memungkinkan mereka memperoleh data yang akurat dan membantu menjaga parkir mobil terbuka untuk kapasitas sebenarnya ( H. G. Jung, 2010).

\subsection{Parkir Mobil Terpadu}

Perhatikan gambar 2 berikut, Customize aplikasi yang cocok untuk berbagai jenis lanskap dan bangunan Struktur tersedia di bawah tanah. Kontrol mudah dengan sentuhan lembut pada layar panel operasi.

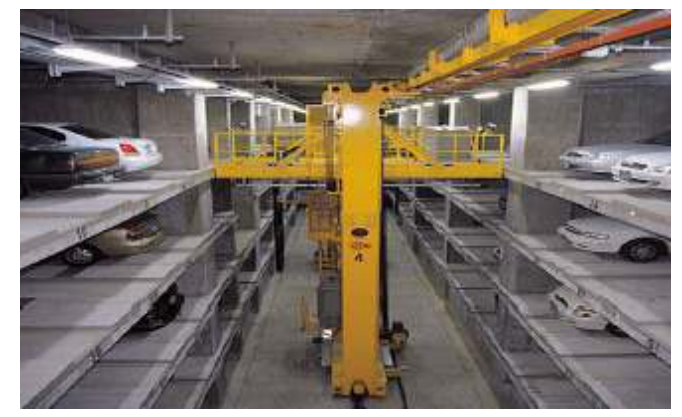




\section{Gambar 2. Parkir Mobil Terpadu}

Ketika kendaraan berhenti di depan pintu masuk, pintu otomatis terbuka dan troli mentransfer kendaraan ke sel parkir. bawah tanah. Dengan investasi ini meningkat dan banyak pemanfaatan ruang banyak yang harus dilakukan.

\subsection{Parkir Mobil Otomatis}

Perhatikan gambar 3berikut, pengemudi akan menarik mobil ke palet yang dikendalikan komputer, mematikannya, dan keluar. Pallet tersebut kemudian diturunkan ke jurang ruang parkir, seperti lift barang untuk mobil, selain itu juga bisa bergerak ke samping, bukan hanya naik dan turun. Ada array sensor laser yang memungkinkan sistem mengetahui apakah mobil tidak muat di palet (meskipun itu cukup besar untuk memuat ukuran menengah SUV). Sistem mengambil mobil ketika pengemudi kembali, meskipun ini mungkin memerlukan beberapa waktu dan manuver kreatif.

Mobil diparkir dua dalam di beberapa tempat, jadi a sistem perangkat lunak yang dirancang khusus harus mencari tahu cara mengangkut berbagai kendaraan di sekitar yang diperlukan ambil mobil tertentu. Dan bagi mereka, seperti saya, yang merasa sulit untuk memutar kendaraan mereka setelah menarik keluar dari ruang, ada meja putar bawah tanah yang mengubah mobil di sekitar sebelum diangkat ke permukaan, sehingga mobil menghadap ke jalan masuk, siap untuk berangkat. Mundur dari garasi atau tempat parkir adalah salah satu penyebab paling umum kecelakaan.

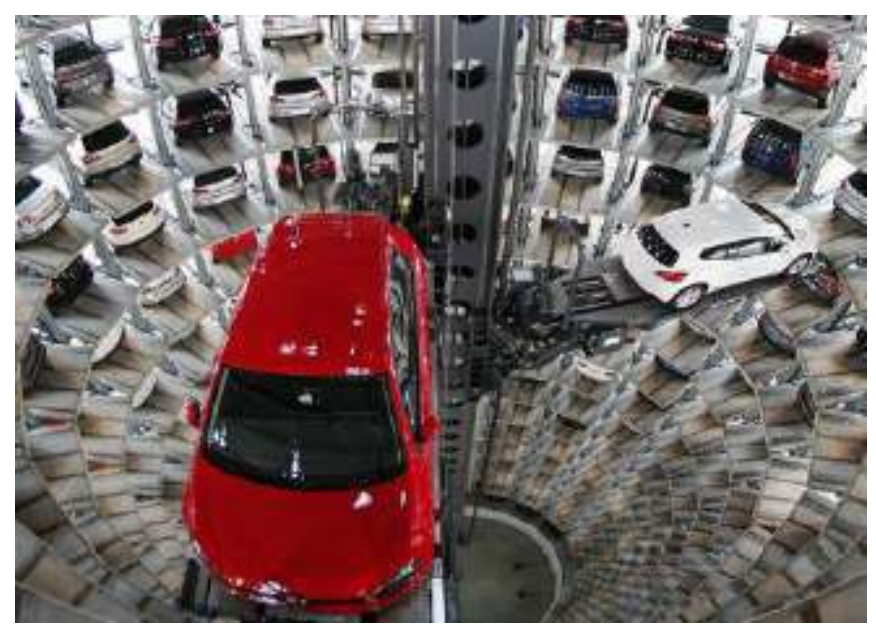

Gambar 3. Parkir Mobil Otomatis

\subsection{Sistem Parkir Pintar}

Sistem parkir pintar adalah sistem yang mengelola kesulitan parkir di kota di area publik atau pribadi, menggunakan beberapa teknologi terkini, termasuk WSN (jaringan sensor nirkabel) dan RFID. (Kalantary, S, 2014), (Akyildiz, I.F.; 2010), (Akyildiz, I.F.; 2002), (Hilmani, A.; 2017).. Sistem ini memperoleh informasi tentang ruang parkir yang tersedia di area parkir menggunakan pengumpulan data real-time oleh node sensor yang tersebar di area parkir, yang memungkinkan pengguna untuk menggunakan layanan tambahan yang diterapkan oleh sistem ini, seperti layanan pembayaran otomatis yang kompatibel 
dengan ponsel, sehingga orang dapat memesan tempat parkir mereka terlebih dahulu. Gambar 1 menggambarkan arsitektur umum sistem parkir cerdas.

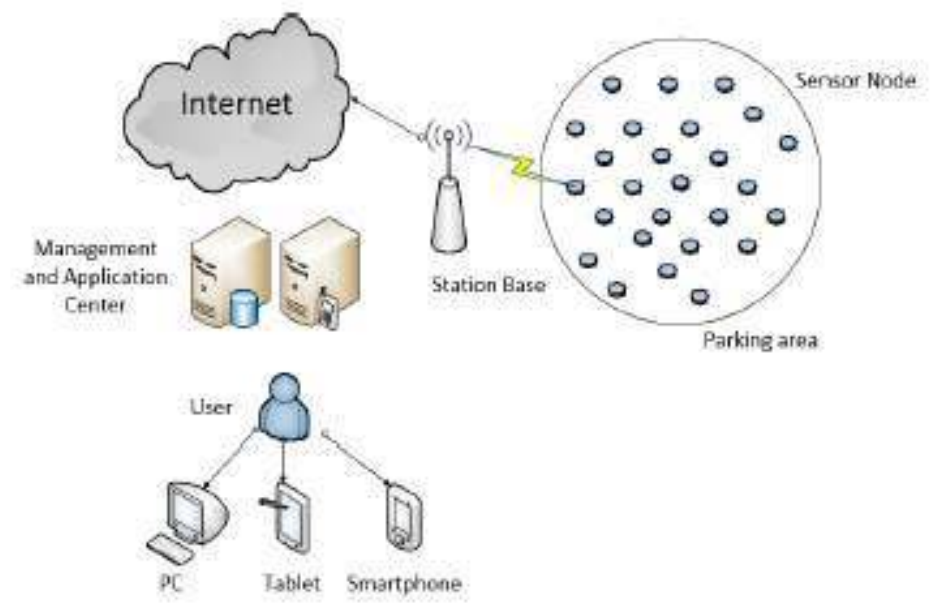

Gambar 4. Sistem Parkir Pintar

\subsection{Parkir Outdoor Linier.}

Sistem ini menawarkan solusi berdasarkan algoritma self-organization yang dapat beradaptasi dan hibrida untuk jaringan wireless sensor networks (WSN), yang memungkinkan untuk menemukan tempat parkir di dua jenis parkir luar ruangan di sebuah kota. Yang pertama adalah "area parkir luar ruang linear" (Gambar 5)

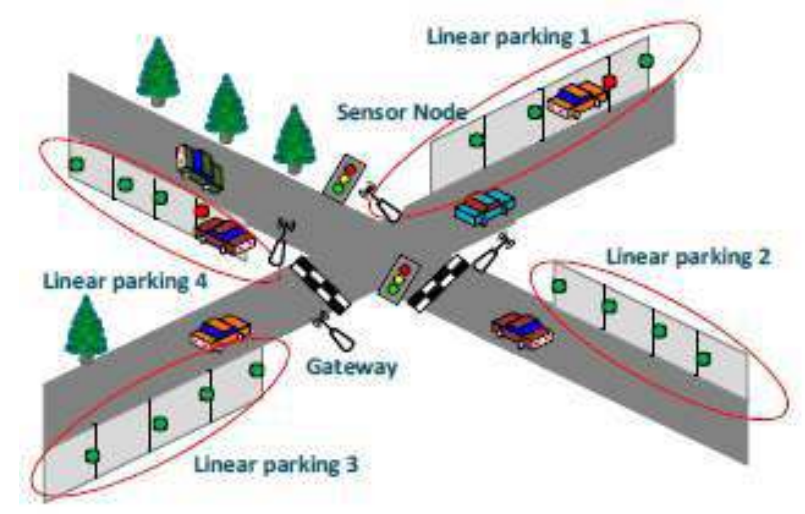

Gambar 5. Parkir Outdoor Linier

Merupakan area parkir yang terletak terutama di jalan utama, gang, dan pusat kota, di mana ruang allparking area parkir membentuk satu baris. Saat ini ada tiga jenis area parkir luar ruang linear (Gambar 6). 


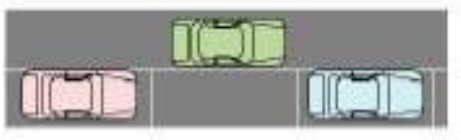

(a)

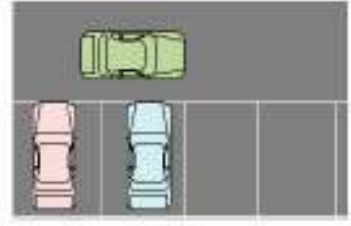

(b)

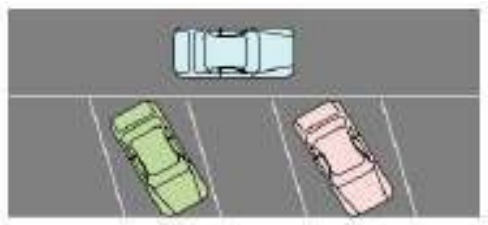

(c)

Gambar 6. Jenis-jenis parkir luar ruang (a) Tipe horizontal; (b) Tipe vertikal; (c) Slashtype.

Parkir tipe Slash adalah yang paling mudah untuk parkir sementara yang paling horisontal sulit, diikuti oleh yang vertikal. Tipe kedua adalah "Parkir luar ruangan massal" yang memiliki tempat parkir yang lebih luas daripada tempat parkir linier dan berada di periferal kota dan di area yang lebih besar seperti taman teknologi, pusat perbelanjaan, dll. (Gambar 7).

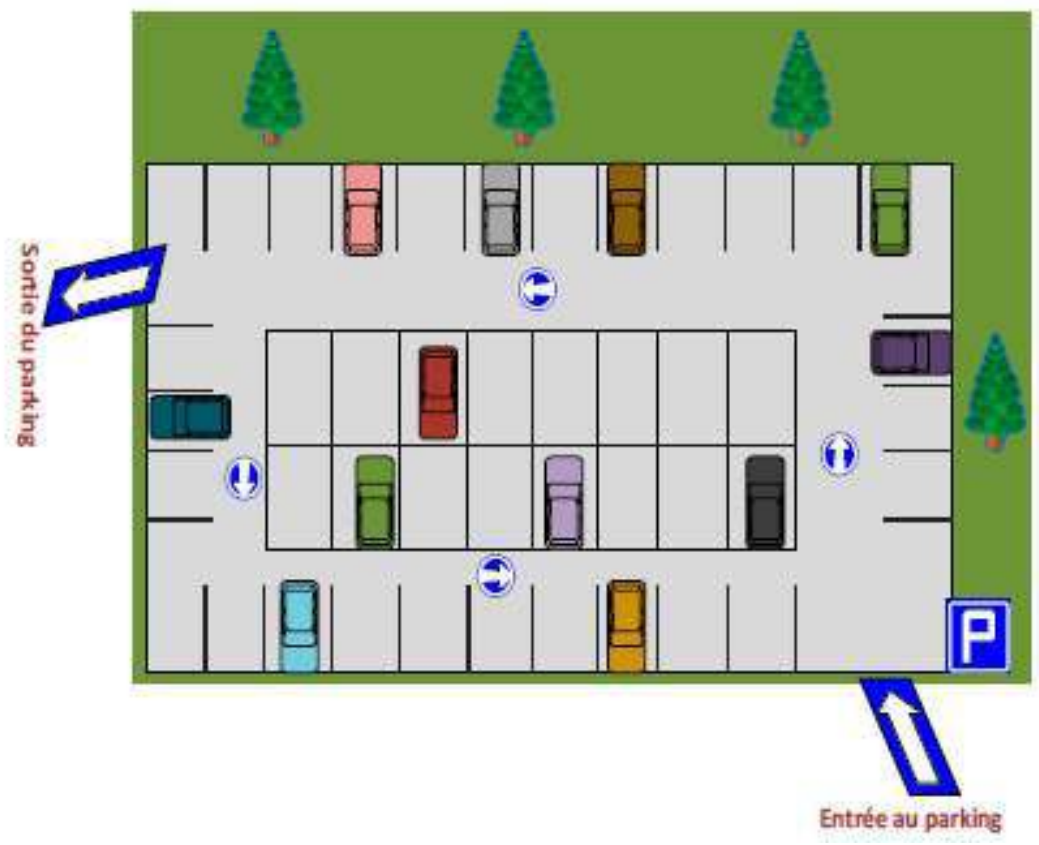

Gambar 7. Parkir Outdor Massal

\subsection{Identifikasi Tag RFID}

Identifikasi frekuensi radio (RFID) adalah metode identifikasi otomatis di mana data yang disimpan pada tag RFID atau transponder diambil dari jarak jauh. Ini akan memungkinkan untuk melihat tempat parkir tanpa awak, aman, parkir yang dikomersialkan dengan teknologi RFID. Masuk dan keluar dari mobil selama parkir akan ditangani secara cepat sehingga masalah kemacetan akan dihindari selama proses ini. Penerapan teknologi RFID membuat parkir efektif, nyaman dan aman. Sistem RFID berdasarkan UHF dan frekuensi yang lebih tinggi menggunakan komunikasi medan jauh dan properti fisik dari hamburan balik atau kekuatan "pantulan". Komunikasi medan jauh didasarkan pada gelombang radio listrik di mana pembaca mengirimkan frekuensi sinyal dasar berkelanjutan yang dipantulkan kembali oleh antena tag. Selama proses, tag 
mengkodekan sinyal yang akan tercermin dengan informasi dari tag menggunakan teknik yang disebut modulasi. Tag aktif memiliki baterai sendiri dan tidak bergantung pada pembaca untuk fungsi apa pun. Tag pasif bergantung pada pembaca untuk kekuatan untuk melakukan semua fungsi. Untuk proyek saya menggunakan tag RFID pasif karena tag tidak memiliki baterai; mereka hanya mengumpulkan energi dari pembaca dan mengirim kembali informasi mereka dan membatasi dengan cara ini jarak antara pembaca dan tag.

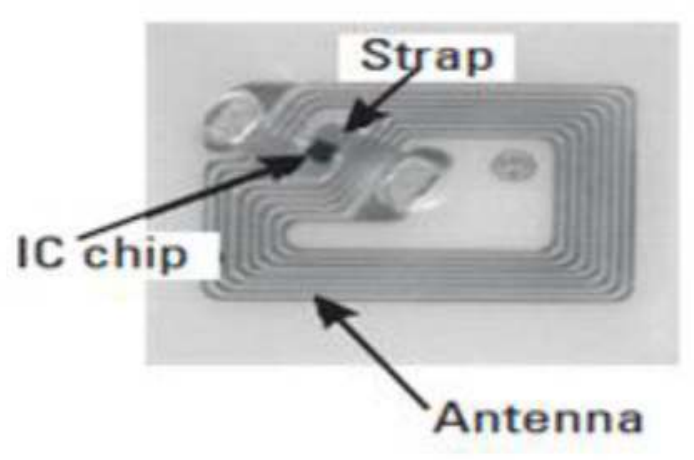

Gambar 8: 13.56-Mhz RFID Tag pasif

Perhatikan gambar diagram berikut 3, Pembaca RFID adalah antarmuka dengan mikrokontroler PIC yang menghubungkan antara sistem parkir kendaraan multilevel. Di sini digunakan tag RFID pasif, sangat nyaman untuk proyek kami. Untuk merancang tag RFID di atas operasi yang disebutkan diikuti. Tag dapat berupa acara dari pembaca yang mendeteksi data dan mengkonversi dari mikrokontroler PIC operasi dilakukan.

\subsection{Algoritama Jalur Terpendek Dijkstra}

Algoritma Dijkstra disebut jalur terpendek sumber tunggal. Ini menghitung panjang jalur terpendek dari sumber ke masing-masing simpul yang tersisa dalam grafik. Algoritma Dijkstra menggunakan pendekatan serakah untuk memecahkan masalah terpendek sumber tunggal. Ini berulang kali memilih dari simpul yang tidak dipilih, vertex v terdekat ke sumber dan menyatakan jarak menjadi jarak terpendek yang sebenarnya dari s ke v.Dijkstra's algoritma bekerja pada pencarian berdasarkan prioritas antara tepi dan simpul. Antrean prioritas menentukan urutan yang berbeda berdasarkan prioritas elemen mereka. Elemen dengan jarak terkecil adalah yang memiliki prioritas tertinggi. Ini memberikan output terbaik dari proyek saya dalam sistem parkir kendaraan multilevel dan yang memberikan penghematan waktu. masalah terpendek tunggal. 


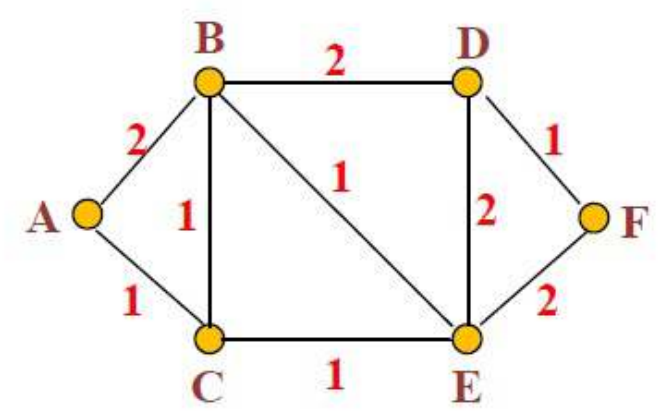

Gambar 9: Path finding Graph

Ini secara berulang kali memilih dari simpul yang tidak dipilih, titik-titik yang berbeda ke dan yang lain. Dialog ini bekerja pada pencarian berdasarkan prioritas antara tepi dan simpul. Antrean prioritas menentukan urutan yang berbeda berdasarkan prioritas elemen mereka. Elemen dengan jarakbelakang adalah yang memiliki prioritas tertinggi. Ini memberikan hasil terbaik dari sistem dalam ruangan parkir multilevel dan yang memberikan penghematan waktu.

\subsection{Sistem Parkir Multilevel}

Diagram ini terdiri dari tag RFID, pembaca RFID yang ditempatkan di depan sistem parkir kendaraan. Mikrokontroler PIC mengendalikan sistem parkir kendaraan menggunakan algoritma terpendek Dijkstra. Sangat mudah dioperasikan dengan pengemudi parkir dan meninggalkan kendaraan di sistem di permukaan tanah. Setelah pengemudi meninggalkan zona aman yang tergabung, kendaraan secara otomatis diparkir oleh sistem yang berputar untuk mengangkat mobil yang diparkir jauh dari posisi tengah bawah. Ini meninggalkan tempat parkir kosong yang tersedia di permukaan tanah agar mobil berikutnya diparkir.

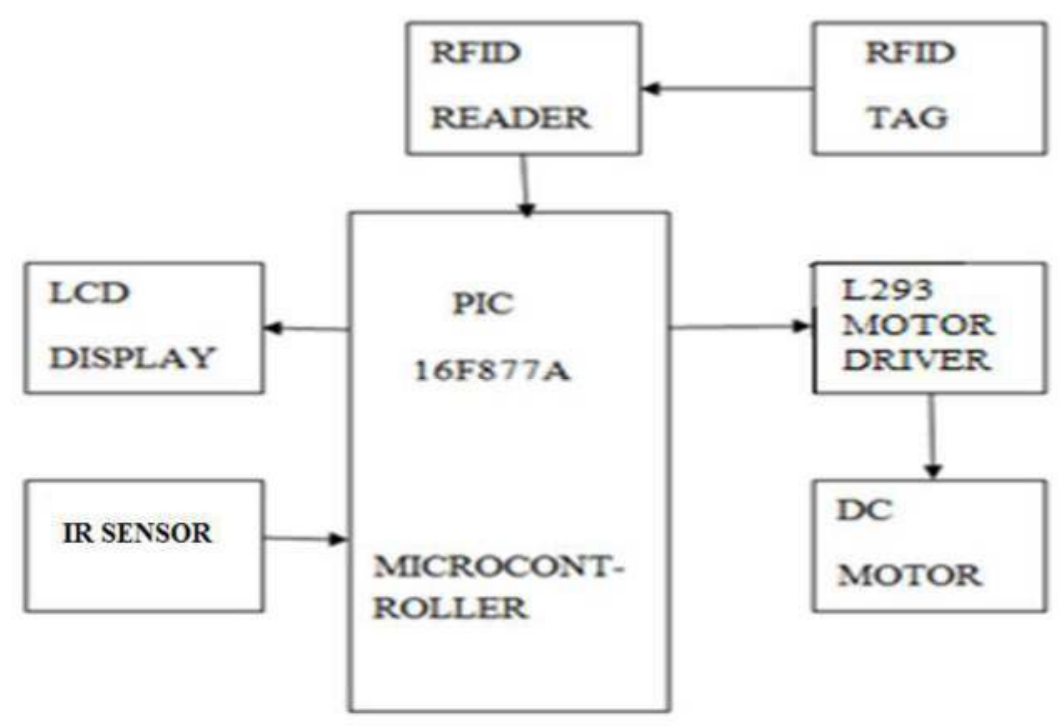

Gambar 10. Block Diagram of Vehicle Parking 
Mobil yang diparkir mudah diambil oleh Down to ground level yang siap untuk pengemudi memasuki zona aman dan membalikkan mobil keluar dari sistem. Kecuali sistem parkir mobil vertikal, semua sistem lain menggunakan area daratan yang luas, sistem parkir mobil vertikal dikembangkan untuk memanfaatkan area vertikal maksimum di area permukaan tanah minimum yang tersedia. Hal ini cukup berhasil ketika dipasang di daerah sibuk yang sudah mapan dan menderita kekurangan tempat parkir.

\section{Arsitektur Sistem Parkir Cerdas}

Sistem yang diusulkan mengandung tiga bagian penting: pusat deteksi parkir, pusat pemantauan parkir, dan pusat manajemen informasi global. Pusat deteksi parkir terutama terdiri dari node sensor hibrid (sensor + pembaca RFID) yang dipasang di setiap tempat parkir di setiap area, node sensor ini membentuk jaringan sensor nirkabel (WSN) yang memungkinkan untuk mengumpulkan keadaan semua ruang parkir (tersedia atau ditempati) untuk mengirim mereka ke gateway (Sink) dari area ini, informasi ini akan dikirim setelah itu ke server pusat untuk menyimpannya di database global. Pusat pemantauan parkir bertanggung jawab untuk mengidentifikasi dan memeriksa mobil yang baru diparkir di ruang yang disediakan atau tersedia. Pusat ini menggunakan teknologi RFID untuk mengontrol dan memantau satu sisi mobil yang diparkir, dan sisi lain, untuk mengidentifikasi dan mengelola pembayaran waktu parkir.

Pusat pengelolaan informasi global adalah basis data tempat semua informasi yang dideteksi dan dikumpulkan dari semua tempat parkir di kota direkam dan dimanfaatkan secara waktu nyata melalui web atau aplikasi seluler. Dengan cara ini, pengemudi akan memiliki semua informasi tentang ruang yang tersedia di semua tempat parkir kota, untuk berkonsultasi dengan ruang-ruang ini sesuai dengan tujuan mereka, dan membayar biaya parkir. 


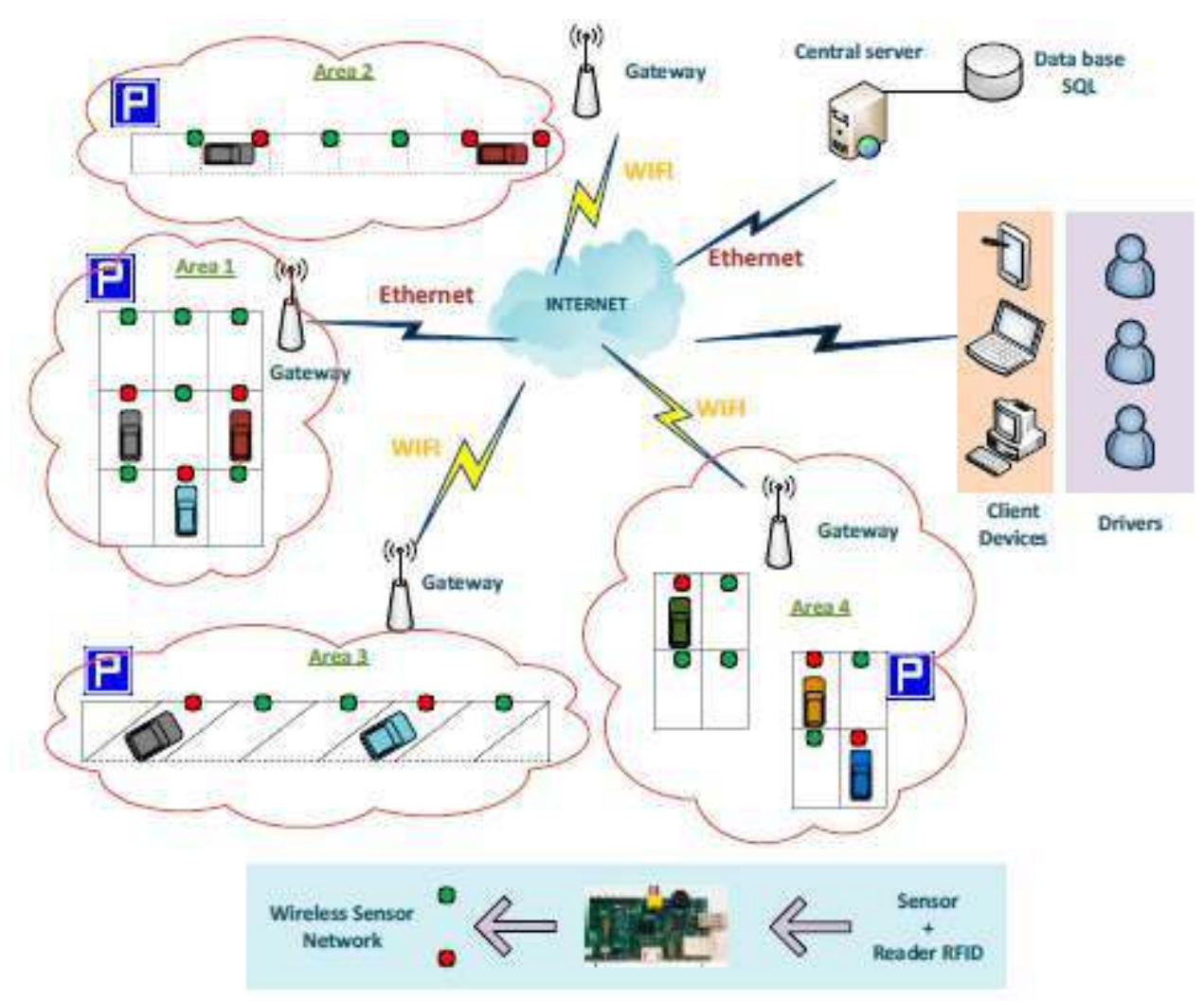

Gambar11. Arsitektur Sistem Parkir Cerdas

\section{Manajemen Parkir Sistem Cerdas}

Pusat deteksi parkir menggunakan dua teknologi, jaringan sensor nirkabel (WSN) dan teknologi RFID. Pembentukan jaringan sensor berubah sesuai dengan jenis parkir di area tersebut. Untuk parkir mobil linier, topologi rantai akan dibentuk di jaringan dan, di sisi lain, topologi jaringan dalam bentuk cluster akan dibuat di tempat parkir massal. Pembentukan topologi yang berbeda didasarkan pada pelaksanaan algoritma swasusun hibrida yang dapat beradaptasi dengan jenis dan struktur parkir yang memungkinkan untuk membentuk rantai (Gambar 12) atau kelompok, sesuai dengan distribusi node dan bagaimana mereka tersebar di area parkir 


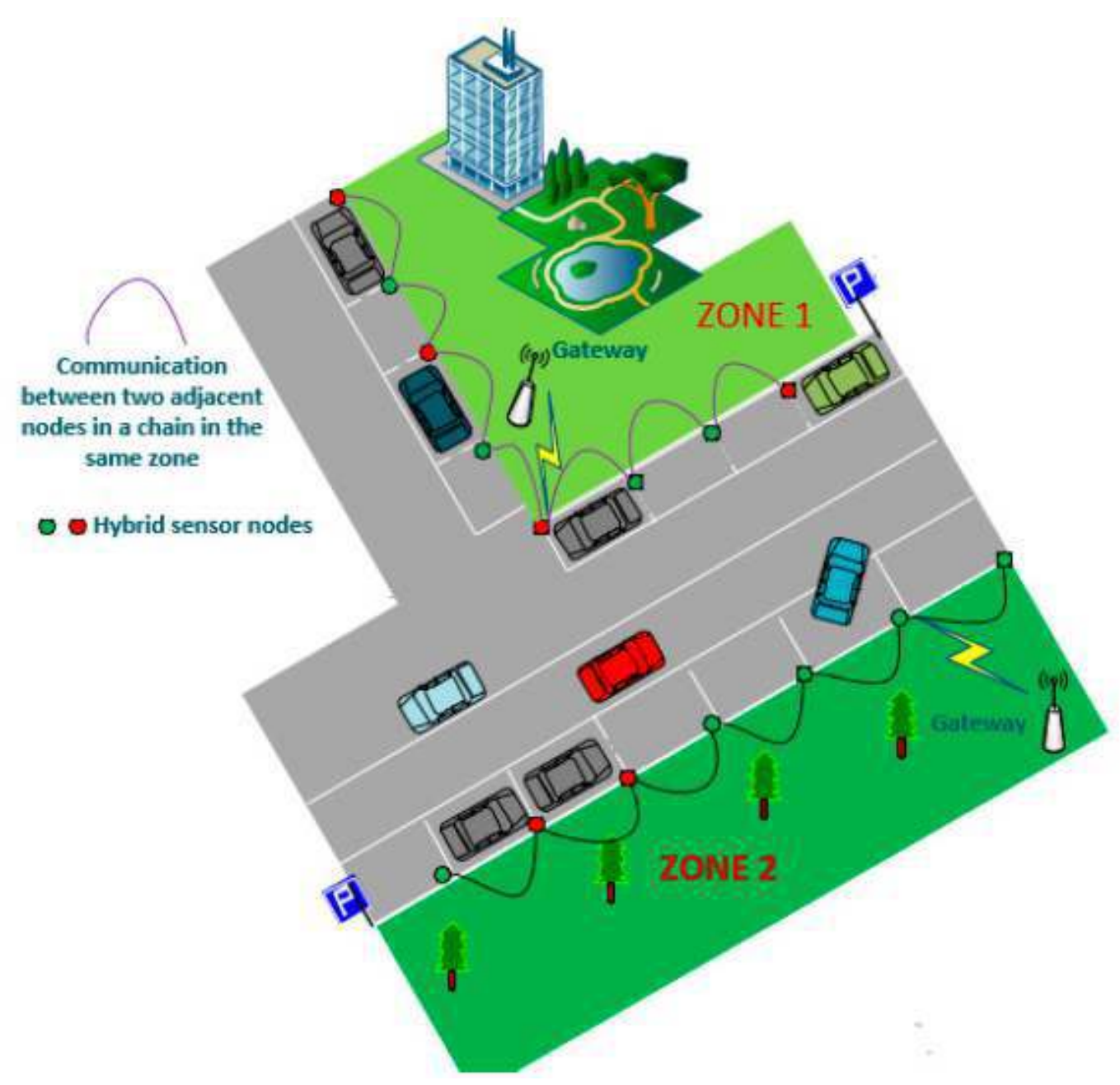

Gambar 12. Pembentukan topologi rantai di parkir linier.

Untuk membentuk topologi jaringan oleh node sensor di parkir luar ruangan, semua node mengirim koordinat mereka ke gateway yang mengeksekusi Algoritma 1 sehingga memungkinkan untuk menghitung dan mendeteksi jenis topologi yang akan dibentuk. Dalam hal parkir linier, gateway mendeteksi bahwa semua node memiliki koordinat $\mathrm{X}$ yang sama atau koordinat $\mathrm{Y}$ yang sama sebagai fungsi distribusi node di area parkir. Dalam hal ini, gateway meminta node untuk membuat topologi rantai di jaringan untuk meminimalkan konsumsi daya antara node menggunakan komunikasi multi-hop ke gateway (Gambar 13).

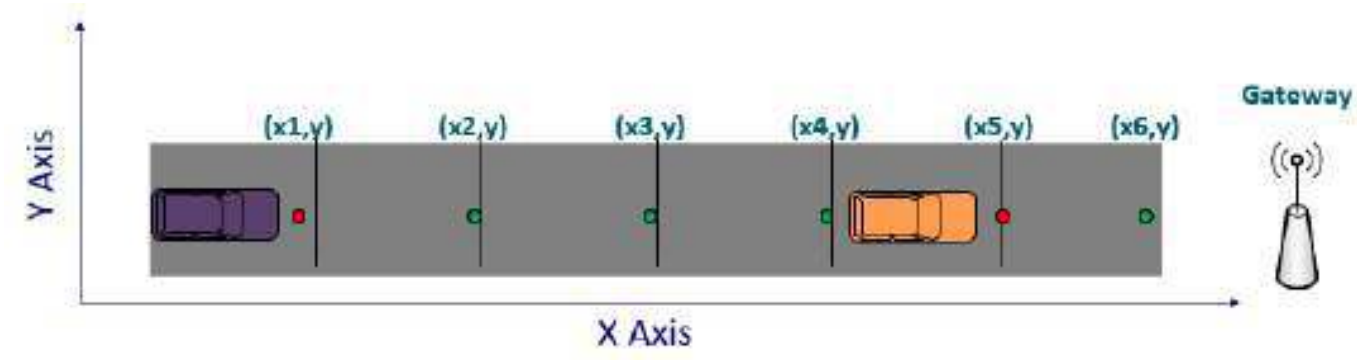

Gambar 13. Contoh distribusi node sensor di area parkir linier 


\section{Pusat Pemantauan Parkir}

Pusat pemantauan parkir menggunakan jaringan sensor nirkabel (WSN) dan teknologi RFID terpadu di node sensor yang dipasang di setiap tempat parkir. Teknologi RFID adalah teknologi yang didasarkan pada identifikasi frekuensi radio yang membantu untuk memeriksa dan mengidentifikasi objek oleh gelombang radio. Dengan demikian, kendaraan akan diidentifikasi dan biaya parkir akan dikumpulkan melalui sistem ini, untuk mengelola dan memantau area parkir secara efisien dan nyaman.

Setelah mobil baru saja parkir di ruang i di area parkir j, sensor yang sesuai mendeteksi keberadaan kendaraan dan mengirimkan dua pengidentifikasi \{IDzi, IDpj\} dengan negara yang ditempati dari ruang itu ke gateway, untuk mentransfernya ke server pusat untuk menyimpannya dalam basis data. Pembaca RFID, terintegrasi di setiap node sensor, membaca data pengemudi menggunakan tag RFID yang dipasang di kendaraan (nama, nama depan, nomor kendaraan, nomor telepon, dll.) Dan mentransfernya dengan menggabungkan kendaraan (nama, nama depan, nomor kendaraan, nomor telepon, dll.) dan transfer mereka dengan menggabungkannya dengan keadaan ruang menuju server pusat. Server ini akan digunakan untuk menghitung durasi parkir dan untuk mengendalikan insiden yang terdeteksi selama parkir kendaraan. Dalam kasus mobil tanpa tag RFID, pesan dikirim ke petugas parkir dengan dua pengenal parkir $\{$ IDzi, IDpj\}, untuk mendaftarkan nomor registrasi kendaraan ke dalam sistem untuk menjamin pembayaran biaya parkir.

Setelah mobil meninggalkan tempat parkir, sensor yang bersangkutan mendeteksi ketersediaan ruang dengan mengirimkan dua pengidentifikasi \{IDzi, IDpj\} ke server pusat melalui gateway sehingga memperbarui keadaan ruang di database. Setelah rilis ruang di database, sistem akan memeriksa apakah pengemudi telah melakukan pembayaran untuk durasi parkir, jika tidak, pemberitahuan pelanggaran dan akan dikirim ke pihak berwenang setelah satu jam sehingga biaya parkir akan dibayar oleh pengemudi.

Pembayaran waktu parkir dilakukan secara online menggunakan aplikasi seluler atau secara manual di mesin kasir otomatis di setiap area. Dalam kedua kasus, hanya nomor registrasi kendaraan yang diparkir yang harus dimasukkan sehingga sistem dapat mendeteksinya dalam basis data dan melakukan pembayaran.

\section{Pusat Manajemen Informasi Global}

Pusat manajemen informasi global bergantung pada data yang disimpan dalam database untuk dikembangkan layanan ekstra untuk pengguna dan pengemudi dengan memfasilitasi tugas mencari ruang yang tersedia di mereka tujuan, seperti konsultasi ruang parkir yang tersedia, navigasi ke ruang-ruang ini, dan juga pembayaran ongkos parkir online. Aplikasi mobile dikembangkan yang memungkinkan driver untuk manfaatkan layanan ini dengan cara yang praktis dan sederhana.

Konsultasi area parkir: Pengemudi menggunakan aplikasi seluler yang memungkinkan mereka untuk berkonsultasi dan menemukan tempat parkir terbuka di dekat tujuan mereka, sebelum pindah untuk menghindari perjalanan yang tidak perlu dan juga tidak menciptakan kemacetan lalu lintas. Aplikasi ini menggunakan informasi yang disimpan dalam basis data untuk disediakan bagi pengemudi, area parkir terbuka yang paling dekat 
dengan tujuan dengan jumlah ruang yang tersedia dan sibuk secara real-time, dengan menunjukkan harga parkir

Navigasi ke area parkir: Layanan ini didasarkan pada penggunaan Google MAP untuk mengarahkan dan memandu pengemudi menuju area parkir yang diinginkan. Pengemudi membuka aplikasi seluler untuk mencari tempat parkir terbuka di dekat tujuannya. Kemudian, tergantung pada hasil yang ditampilkan oleh aplikasi, pengemudi memilih area parkir dan aplikasi membuka Google MAP untuk memandu pengemudi ke area yang dipilih. Begitu tiba di area tersebut, aplikasi menampilkan ruang yang tersedia dan kotak sibuk di area parkir ini. menggambarkan pengoperasian navigasi ke area parkir.

Pembayaran biaya parkir: Sebelum meninggalkan tempat parkir, pengemudi harus membayar biaya parkir, pembayaran ini dilakukan secara manual dengan berpindah ke mesin kasir otomatis dari tempat parkir dengan memasukkan nomor registrasi kendaraan. Baik secara online, pengemudi menggunakan aplikasi seluler yang sama dengan manipulasi yang sama dari mesin kasir otomatis untuk mewujudkan pembayaran biaya parkir di area parkir ini.

\section{Kesimpulan}

Tidak ada sistem yang menyesuaikan dengan berbagai jenis arsitektur dan struktur parkir. Ada sistem parkir yang hanya berfungsi untuk parkir mobil linier dan tidak memiliki dampak yang sama pada tingkat penyebaran jaringan sensor di parkir massal, dan sebaliknya. Kompleksitas algoritma yang digunakan dalam pengelolaan ruang parkir memainkan peran penting dan penting dalam pengembangan dan desain sistem parkir cerdas yang andal dan efisien. Sebagian besar algoritma yang diusulkan oleh sistem kami tidak rumit, mereka mudah untuk diimplementasikan, dan mereka dijalankan di tingkat server, yang meminimalkan kelelahan sensor dan tidak membebani mereka, sehingga mereka tidak mengkonsumsi besar jumlah energi untuk meningkatkan durasi masa pakai baterai mereka.

Efisiensi energi adalah salah satu parameter penting untuk banyak algoritma selforganization yang memungkinkan penciptaan topologi jaringan yang solid untuk mengoptimalkan konsumsi energi antara node sensor yang berbeda dan untuk meningkatkan umur panjang dari jaringan WSN. Algoritma self-organization yang diadopsi oleh sistem kami adalah algoritma yang fleksibel dan unik, dibandingkan dengan algoritma yang diterapkan oleh sistem parkir cerdas yang dipelajari dalam artikel ini, yang memungkinkan penciptaan rantai topologi untuk area parkir linier dan topologi klaster untuk area parkir massal, untuk menyeimbangkan beban antara sensor yang berbeda dan meminimalkan konsumsi energi selama transmisi data untuk mendapatkan manajemen efisiensi energi yang lebih baik dan meningkatkan masa pakai node.

Untuk alasan ini, kami akan menawarkan sistem parkir cerdas yang mudah beradaptasi yang memungkinkan terciptanya topologi jaringan WSN yang fleksibel untuk semua jenis parkir yang ada di kota, berdasarkan banyak layanan dan teknologi yang menawarkan kemudahan kepada pengemudi. Teknologi sistem dengan arsitektur sensor nirkabel yang dapat beradaptasi (WSN) memberikan fleksibilitas dan keluwesan dalam penyebaran sistem parkir cerdas yang akan monoton dalam desain dan implementasi, dan juga akan distandarisasi dalam pengembangan aplikasi dan layanan untuk berbagai jenis dan 
struktur parkir mobil yang ada, dengan mengingat bahwa solusi ini menciptakan dasar yang kuat untuk pengembangan dan peningkatan sistem ini di masa depan, sesuai kebutuhan. Sistem parkir cerdas yang diusulkan dalam artikel ini didasarkan pada penerapan dua teknologi terbaru, seperti WSN dan RFID. Penggunaan kedua teknologi ini hanya memberikan nilai plus dibandingkan dengan sistem manajemen parkir lainnya dalam hal biaya pelaksanaan dan juga dalam hal kualitas desain.

Dalam hal ini, studi komparatif menyeluruh dari berbagai arsitektur dan protokol selforganization yang berbeda yang digunakan dalam pengelolaan berbagai jenis parkir mobil yang ada di kota-kota. Juga usulan arsitektur dari sistem parkir cerdas berdasarkan penyebaran dan penerapan teknologi yang berbeda, seperti WSN, IoT, RFID. Arsitektur ini mengimplementasikan, di satu sisi, protokol self-organisation hibrida dan adaptif baru untuk penyebaran node sensor di lingkungan yang berbeda untuk memaksimalkan kinerja

WSN dan meningkatkan umur panjangnya, dan, di sisi lain, menggunakan echnologies yang ada, seperti WSN dan RFID untuk meminimalkan biaya penerapan sistem dan meningkatkan kualitas desainnya. Dalam pekerjaan di masa depan, kami akan merinci dan mengembangkan protokol self-organization baru yang dapat beradaptasi ini untuk jaringan sensor nirkabel dengan melakukan simulasi untuk menunjukkan kekuatannya dengan membandingkannya dengan protokol self-organization lain yang ada.

\section{Daftar Pustaka}

[1] Akyildiz, I.F.; Vuran, M.C. (2010). Wireless Sensor Networks; Wiley Publication: Hoboken, NJ, USA, 2010.

[2] Akyildiz, I.F.; Su,W.; Sankarasubramaniam, Y.; Cayirci, E. A survey on sensor networks. IEEE Commun. Mag. 2002, 40, 102-114

[3] Ayesha Haroon. (2015). Raspberry-Pi (On-Board Computer) Based Intelligent Vehicle Parking System." International Journal of Technology and Research: Vol. 3, No 1 .

[4] F. Shaik, P. Jadhav, S. Bhandarkar, O. Kulkarni, N. Shardoor. (2016) Smart Parking System Based on Embedded System and Sensor Network. .International Journal of Computer Applications (0975-8887) Volume 140-No. 12.

[5] Hanche, S. C., (2013). Automated Vehicle Parking System using RFID.Volume-1, Issue-2

[6] Hilmani, A.;Maizate, (2017. )A. A study of self-organization protocols in wireless sensor network.Mediterr. Telecommun. J.

[7] J. Takahashi, K. Sekiyama, T. Fukuda, (2009) "Cooperative Object Tracking With Mobile Robotic Sensor Network", Distributed Autonomous Robotic Systems. Springer, Berlin, pp 51-62.

[8] Kalantary, S.; Taghipour, S. (2014). A survey on architectures, protocols, applications, and management in wireless sensor networks. J. Adv. Comput. Sci. Technol.

[9] K. Pardeshi. (2015)., Design and Implementation of Smart Car Parking System (SCPS) using Raspberry Pi.. International Journal of Scientific Research \& Development Vol. 3, Issue 07.

[10] R. Yusnita, F. Norbaya, N. Basharudin. (2012). Intelligent Parking Space Detection System Based on Image Processing. International Journal of Innovation, Management, and Technology, Vol. 3, No. 3. 
[11] S. Lee, D. Yoon, A. Ghosh, "Intelligent Parking Lot Application Using Wireless Sensor Networks", International Symposium on Collaborative Technologies and Systems, pp.48-57, 19-23 May 2008.

[12] ttp://www.ops.fhwa.dot.gov/congestion_report/chapter3.htm\#footer14 